\title{
A survey of tax compliance costs of Flemish SMEs: magnitude and determinants
}

\author{
Bilitis Schoonjans, Philippe Van Cauwenberge $\uparrow$, Catherine Reekmans, Gudrun Simoens \\ Department of Accountancy and Corporate Finance, Ghent University, Kuiperskaai 55/E, B-9000 \\ Ghent, Belgium; e-mail: Bilitis.Schoonjans@UGent.be, Philippe.Vancauwenberge@UGent.be, \\ Catherine.Reekmans@UGent.be, Gudrun.Simoens@UGent.be \\ Received 18 October 2010; in revised form 3 February 2011
}

\begin{abstract}
This study presents survey evidence on the magnitude and determinants of tax compliance costs in Flemish small and medium-sized enterprises (SMEs). Data were obtained from an Internet questionnaire among members of a professional network of Flemish entrepreneurs, called VOKA. Analyzing a sample of 151 Flemish SMEs, we find that the tax compliance costs-exceeding over 7\% of gross added value - are relatively high. Value-added tax, labor taxes, and corporate taxes are the main components of tax compliance costs. In addition, our evidence confirms the regressivity hypothesis, according to which smaller companies face relatively higher compliance costs. Furthermore, industry, age, and the proportion of blue-collar workers prove to be determining factors of relative compliance costs. Our study concludes by formulating a number of policy recommendations that might contribute to lower compliance costs.
\end{abstract}

\section{Introduction}

Researchers and practitioners interested in the tax burdens of companies almost exclusively focus on direct tax costs (eg, Slemrod, 2004; Vandenbussche et al, 2005). However, in addition to tax payments, companies are confronted with costs to comply with the tax legislation, and these costs can be significant. Small and medium-sized enterprises (SMEs) are especially burdened by compliance costs as they often do not have in-house specialists to deal with the many bureaucratic and legal knowledge requirements (Gurd et al, 1998). In fact, tax compliance costs (TCCs) rank among the top burdens as perceived by SMEs (O'Reilly, 2005). For instance, for the UK Chittenden et al (1999) show that $25 \%$ of the total tax burden for small limited companies is related to self-reported costs of compliance. Despite heightened public and political sensitivity for TCCs, there are only a handful of empirical studies investigating this topic. With the intention of broadening the empirical evidence, we examine the TCCs of Belgian SMEs located in Flanders. To our knowledge we are the first to do so. As well as being characterized for its high tax rates on companiesthe Belgian total tax burden is as high as $58 \%$ - Belgium is a particularly interesting country to assess TCCs in the sense that it has a very complex tax system. There are no fewer than ninety-two different taxes imposed by the Belgian authorities (overview in appendix). This is a very high number compared with other countries. In the UK, for example, only twenty-two charges exist and in Australia fifty-six taxes are levied (PwC and Federation of Enterprises in Belgium, 2009). Moreover, new taxes are frequently introduced in Belgium and existing charges are often adjusted. This results in new compliance costs because of initial learning costs (Holtzman, 2007). Of the ninetytwo taxes imposed by the Belgian tax system, thirty-nine are taxes collected. Taxes collected are taxes such as employee social security contributions that are gathered and subsequently transferred to the government by a company. Contrary to taxes borne (eg corporate taxes), these taxes will not directly affect a firm's results. However, the taxes collected often generate the highest part of a company's compliance costs and thereby indirectly influence a company's bottom line. Firms act as subcontractors of

$\uparrow$ Corresponding author. 
the government for the collection of taxes without having the possibility to charge a fee for these services. Nevertheless, it must be noted that taxes collected can also induce cash flow benefits. A time lag often exists between the moment of tax collection and the moment of cash transfer to the government. Companies can benefit from these temporary cash flows by taking them into account in their cash-flow management (Tran-Nam et al, 2000).

Our study focuses on SMEs because, as in many countries, they are increasingly important for the economy, not least in terms of employment. In Belgium $99.4 \%$ of the companies are SMEs and they generate more than $70 \%$ of the gross domestic product. High compliance costs can diminish small firms' profitability and consequently can slow down economic growth.

The remainder of this paper is organized as follows: in section 2 we provide a definition of TCCs and a literature review. In section 3 we discuss our methodology. In section 4 we present our empirical findings, while in section 5 we conduct a sensitivity analysis. In section 6 we discuss a number of policy recommendations that might contribute to reducing compliance costs. We conclude in section 7.

\section{Definition and literature review}

TCCs can be defined as the costs incurred by taxpayers in meeting the requirements laid on them by tax law and the revenue authorities, in addition to the tax liability itself (Sandford, 1995). According to Smulders and Stiglingh (2008), TCCs typically include the following elements: (1) the amount of time spent by business owners, managers, staff, and others on understanding and applying the rules, (2) record-keeping costs, (3) the payments for the expertise of professional advisors such as consultants, lawyers, and accountants, and (4) incidental costs such as postage, telephone, and travel in communicating with advisors or the tax authorities. These compliance costs are generally inevitable and irreducible (Tran-Nam et al, 2000). Moreover, they are difficult to calculate in detail, which causes the costs to remain hidden between other administrative costs. Companies are therefore often not aware of the adverse consequences that compliance costs have on their profitability. In addition, high compliance costs can inhibit foreign investors from making new investments, as they often base their investment decisions on the tax regimes that are applicable in a particular country. Indeed, tax legislation appears to be an important factor in the competition for external investments between different countries. A lack of external investments can slow down economic growth, innovation, and technological progress (PwC and World Bank Group, 2008).

Although the empirical research on TCCs is scarce, there have been a number of investigations in certain countries and regions around the world, among which are the US (Slemrod and Venkatesh, 2002), Australia (Pope, 1993), Canada (Soufani, 2003), the UK (Hansford et al, 2003; Poutziouris et al, 1999; Sandford, 1995), Singapore (Ariff et al, 1997), and Hong Kong (Chan et al, 1999). (1) A problem with international comparisons, however, is that there is no common definition of compliance cost and no accepted methodology to obtain empirical assessments (Chittenden et al, 2003). While cross-country comparisons are therefore difficult to conduct and should be treated with care, there nonetheless seems to be consensus that TCCs are significant.

With regard to the determinants of the cross-sectional variation within a country of TCCs, there are a number of common variables that appear regularly in the empirical literature.

(1) A review of the literature on compliance costs in the USA, the UK, Australia, and New Zealand is provided in Chittenden et al (2003). 


\subsection{Size}

Several studies document a negative relation between company size and compliance costs relative to turnover (Blumenthal and Slemrod, 1992; Hanefah et al, 2002; Pope, 1993; Sandford et al, 1989; Slemrod and Venkatesh, 2002; Vaillancourt, 1986). In a comprehensive review of administrative and compliance costs of goods and services taxes (GSTs), Cnossen (1994) indicates that the relative compliance costs related to GSTs predominantly encumber SMEs. The reason that small businesses bear higher relative compliance costs can partly be explained by the fact that compliance costs are to a certain extent fixed. Therefore, large firms can enjoy economies of scale in their compliance costs. Furthermore, Chittenden et al (2005) show that the highly regressive nature of pay-as-you-earn (PAYE) and National Insurance contribution compliance costs is primarily caused by the number of hours that business owners and directors spend on the administration of PAYE. At start-up, business owners will perform many tax administration tasks themselves, whereas in later growth stages these tasks will be delegated to 'less expensive' administrative employees.

\subsection{Outsourcing}

In large companies most routine tasks related to fiscal administration are performed internally. Additionally, more complex tasks can be outsourced to external consultants (Blumenthal and Slemrod, 1996). Small companies often lack the scale to develop in-house expertise. However, whether this is a disadvantage is an empirical question, the outcome depends on the number of hours spent and the relative hourly prices of internal and external resources. In addition, Coolidge et al (2009) warn about the disadvantages of applying partial outsourcing. Partial outsourcing is not efficient when many tasks are duplicated internally and externally.

\subsection{Industry}

Most country studies investigate the diversity of compliance costs across industries (Blumenthal and Slemrod, 1996; Chan et al, 1999; Slemrod and Venkatesh, 2002). In general, there seems to exist a wide variation in TCCs by industry. For example, Blumenthal and Slemrod (1996) show that firms in the retail or wholesale industry have significantly lower TCCs on average, and firms in primary industry have significantly higher costs. Nevertheless, no unequivocal conclusions can be drawn concerning which industries are burdened most by tax compliance.

\subsection{Workforce}

A fraction of the ninety-two Belgian taxes are employee related (employee social security contributions, employer social security contributions, personal income tax, etc). It is obvious that the number of employees will have an impact on absolute compliance costs. The proportion between the number of blue-collar workers and the total work force (white collar and blue collar) can also be a determining factor. In Belgium white-collar workers are more likely to receive a wider range of employee benefits than blue-collar workers. However, employee benefits can cause high TCCs. Hence, firms with a high proportion of white-collar workers might have greater TCCs. Finally, Collard and Godwin (1999) show that casual employment can drastically increase compliance costs. TCCs for the administration of casual employees appear to be approximately twice as high as those for part-time employees. Furthermore, full timers appear to increase compliance costs to a larger extent than part timers. 


\section{Methodology}

\subsection{Data collection}

Similarly to most studies in this area, our data were obtained by an electronic Internetbased anonymous survey. ${ }^{(2)}$ The survey was conducted among members of VOKA, which is a professional network of Flemish entrepreneurs (http://www.voka.be). The questionnaire was developed by a team consisting of academics, members of the research team of VOKA, and tax practitioners. To ensure that the questions in the survey were unambiguous, comprehensible, and relevant, a pilot study was conducted. This pilot study took place at a predetermined educational event organized by VOKA among a group of entrepreneurs. The survey was introduced as an Internet link in a covering e-mail. This mail was signed by the University of Ghent and VOKA to stress the anonymity and official character of the survey. The survey was directed to the entrepreneurs and not to tax practitioners. However, in the survey the entrepreneurs were requested to forward the survey to their tax consultants if (part of) the compliance task was outsourced, after filling in their internal compliance costs (if any). Afterwards, the input from the entrepreneurs and the tax consultants was totaled per company.

Although most studies ask a direct estimate of total TCCs, our pilot testing showed that more detailed questioning resulted in more accurate estimations of compliance costs. Therefore, the survey asked about compliance cost per category at a fairly disaggregated level of tax categories (see table 1). A potential advantage of using a lower level of aggregation in taxes than is normally used in the literature on compliance costs was that it decreased the possibility that some tax categories might be overlooked by respondents. Furthermore, the respondents were questioned about all possible costs involved in the tax filing process. These costs include prefiling (eg followup of new fiscal legislation, forecasting of tax payments), filing (eg calculation of the tax arrears, execution of the tax payments), and postfiling (eg control and auditing services) costs.

Table 1. Calculation of absolute tax compliance cost (TCC).

Prefiling, filing, and postfiling costs of value-added tax (VAT), customs, and excise duties

+ prefiling, filing, and postfiling costs of corporate income tax

+ prefiling, filing, and postfiling costs for withholding and property taxes

+ prefiling, filing, and postfiling costs of environmental taxes

+ tax compliance component of the labor taxes ${ }^{\mathrm{a}}$

+ consulting and lawyer costs concerning fiscal items

+ tax compliance component of auditing costs

+ preparation and execution of prepayments

+ costs related to AOIF control and general tax controls ${ }^{\mathrm{b}}$

+ costs related to VAT control

+ compliance costs related to provincial and municipal taxes

$=$ Total TCC

a Throughout the paper, we use the term labor taxes to indicate the compliance costs related to the total of employee social security contributions, employer social security contributions and personal income tax.

${ }^{\mathrm{b}}$ AOIF denotes 'Administratie voor Ondernemings-en Inkomensfiscaliteit' (Administration for Business and Income Taxation).

(2) By using a web-based survey, we exclude businesses that do not use electronic platforms. However, as argued by Guyton et al (2005), tax software might lower compliance costs to some extent. Consequently, if these companies do not make use of electronic platforms for their tax administration, tax compliance costs might be somewhat underestimated in our sample. The survey is available on request. 
As revealed by the pilot testing, a disadvantage of our detailed questioning was that the survey proved to be rather time consuming. To alleviate the disincentive effect caused by this, participants were stimulated by a reward. By means of a web application, respondents' own compliance costs were computed and were displayed to them immediately after full completion of the questionnaire. This postsurvey 'reward' not only created an incentive to participate, but also provided a motivation for participants to provide accurate answers in order to increase the realism of their own total compliance cost estimate.

The survey consisted of two parts. The first was used to gather firm identification data (number of employees, main business activity, etc). In the second part, participants were asked to provide information about the compliance costs of the firm. For each tax item respondents could choose whether they estimated the total compliance cost of the item or the time spent on the compliance activities related to the item. In order to compute the tax compliance cost in the latter case, a rate of $€ 70$ per hour was used for external services and a lower rate of $€ 50$ per hour for internal services. Both hour rates are considered before-taxes measures of cost. These rates were based on estimated average market prices. In the pilot study, internal and external accountants confirmed these rates to be representative for Belgian companies. The reason why respondents could also opt for estimating their time spent was the fact that the pilot study had revealed that some participants felt more comfortable estimating time units while others preferred monetary amounts.

\subsection{Sample}

As mentioned, our sample consists of SMEs that are members of VOKA. For our survey, and in line with the European Commission's definition, we defined an SME as a company with a workforce of a maximum of 250 employees. We excluded nonprofit organizations, banks and insurance companies, and public service providers. This elimination is in line with other empirical work (eg, Blumenthal and Slemrod, 1996) and is motivated by the fact that these organizations face specific fiscal regulations. In addition we omitted sole proprietors and other firms that are not liable to corporate taxation but instead fall under the personal tax regime. After deletion of companies with no e-mail address, our final mailing list consisted of 10300 Flemish SMEs. The questionnaire was sent to the whole mailing list. After two weeks, a follow-up mail was sent to all companies that had not responded in order to increase the response rate. Eventually 184 responses were received, which corresponds to a $1.8 \%$ response rate. Some thirty-three returned questionnaires could not be used because of incomplete or unreliable answers. Consequently, our final sample consists of 151 acceptable responses.

\subsection{Variables}

Table 1 shows how the absolute TCC is calculated. For each item, respondents could choose whether they estimated the total compliance cost of the item or the time spent on the compliance activities related to the item. In order to compute the TCC in the latter case, a rate of $€ 70$ per hour was used for external services and a lower rate of $€ 50$ per hour was used for internal services.

- Outsourcing is a dummy variable indicating 1 if a company partially outsources (ie makes use of an internal and an external accountant) and 0 otherwise.

- The blue-collar workers ratio is defined as the proportion of blue-collar workers in the total workforce.

- Industry is a dummy variable taking the value of 1 if a company is operating in the services industry and 0 if it is situated in the manufacturing industry. 


\subsection{Nonresponse bias}

In order to detect potential nonresponse bias, the extrapolation approach suggested by Armstrong and Overton (1977) was followed. Their method assumes that late respondents are similar to nonrespondents. Therefore, we examined whether significant differences in TCCs between early and late respondents existed. Our analysis shows that early and late respondents do not differ significantly in terms of absolute TCCs $(p=0.9914)$, compliance costs relative to assets $(p=0.4827)$, and compliance costs relative to gross added value $(p=0.9789)$. On the basis of this evidence there are no indications of nonresponse bias in our sample.

\section{Estimation results}

\subsection{Descriptives}

Table 2 presents some descriptive statistics from the companies that participated in the survey. The average SME in our sample has $€ 6853273$ of total assets and an added value of $€ 2234167$. Some $55 \%$ of the SMEs are partially outsourcing, $86.1 \%$ are older than ten years and $58.28 \%$ of the firms have fewer than twenty employees. ${ }^{(3)}$ Furthermore, $60.3 \%$ of the SMEs operate on an international scale. The average percentage of blue-collar workers is $46 \%$.

Table 2. Descriptive statistics.

Variable $\quad N \quad$ Minimum Maximum Mean $\begin{aligned} & \text { Standard } \\ & \text { error }\end{aligned}$

Tax compliance costs (TCCs)

Absolute TCC

151

$\begin{array}{rr}3824.700 & 80032.500 \\ 0.001 & 0.104 \\ 0.003 & 0.376\end{array}$

26230.540

0.021

21730.910

TCC relative to assets

146

0.003

0.071

0.029

TCC relative to gross added value

139

$\begin{array}{cc}85.908 & 39349.800 \\ 14.500 & 11914.000 \\ 0 & 1 \\ 0 & 1 \\ 0 & 1 \\ 0 & 1 \\ 0 & 1\end{array}$

6853.273
2234.167
0.550
0.603
0.861
0.305
0.460

10561.490

3215.106

0.499

0.491

0.347

0.462

151

Blue-collar workers

151

Note: absolute TCC, TCC relative to assets, TCC relative to gross added value, total assets, and added value are winsorized at the 5th and 95th percentiles in order to mitigate the effect of outliers; observations with added values smaller than 0 are deleted from the sample.

Table 3 shows the size and industry distribution of our sample. The sample distributions are compared with the distributions of the population of Flemish SMEs, which are retrieved from the BelFirst database of the Bureau Van Dijk. ${ }^{(4)}$ Table 3(a) displays the size distribution, where size is measured as the number of employees. Both the sample and population distribution are clearly highly right skewed, which is typical for this kind of size distribution. In our sample, however, smaller companies seem underrepresented. Some $58.28 \%$ of the sample companies have zero to twenty employees, whereas the equivalent is $90.48 \%$ for the total population. If compliance costs prove to be regressive in nature, this might cause underestimation of the TCCs of

(3) Working owner-directors are not included in the number of employees.

(4) Belfirst is a database containing detailed information about the financial statements of Belgian and Luxembourg companies. The database is provided by Bureau Van Dijk. 
Table 3. Size and industry distributions: (a) size distribution; (b) industrial distribution.

$\begin{array}{lll}\text { Sample } & \begin{array}{l}\text { Percentage } \\ \text { of sample }\end{array} & \begin{array}{l}\text { Population of } \\ \text { Flemish SMEs }(\%)\end{array}\end{array}$

\begin{tabular}{lrrr}
\hline (a) Number of employees & & & \\
$0-4$ & 47 & 31.13 & 62.41 \\
$5-20$ & 41 & 27.15 & 28.07 \\
$21-50$ & 28 & 18.54 & 6.57 \\
$51-100$ & 17 & 11.26 & 1.87 \\
$101-150$ & 11 & 7.28 & 0.59 \\
$151-200$ & 2 & 1.32 & 0.32 \\
$201-250$ & 5 & 3.31 & 0.16 \\
Total & 151 & 100.00 & 100.00 \\
& & & \\
(b) Industry & & & \\
Primary industry & 6 & 3.97 & 2.24 \\
Production & 37 & 24.50 & 9.67 \\
Construction & 18 & 11.94 & 15.02 \\
Wholesale and retail & 44 & 29.14 & 26.92 \\
Hotels and restaurants & 2 & 1.32 & 5.86 \\
Transport and storage & 6 & 3.97 & 4.16 \\
Real estate & 5 & 3.31 & 8.96 \\
Other services & 33 & 21.85 & 27.17 \\
& & & \\
Total & 151 & 100.0 & 100.00
\end{tabular}

Note: SME—-small and medium-sized enterprise.

Flemish SMEs in our sample. Table 3(b) documents the distribution of the responding firms according to industry. Similar to the population firms, the majority of the sample firms are active in wholesale and retail, construction, and other services. However, the production sector is overrepresented in the sample while other services are underrepresented. Since some sector classes are fairly small in our sample, we have opted to aggregate the industry groups into two classes for the statistical analyses: 'manufacturing' (consisting of the first four industry categories in table 3) and 'services' (consisting of the last four industry categories in table 3). The service industry is underrepresented in our sample (30.45\% compared with $46.15 \%$ for the population), whereas the manufacturing industry is overrepresented $(69.55 \%$ compared with $53.85 \%$ for the population). If compliance costs prove to be higher for the service industry, this might cause underestimation of the TCCs of Flemish SMEs in our sample.

Figure 1 indicates that VAT (50\%), labor taxes (21\%), and corporate taxes $(11 \%)$, totaling $80 \%$, are the main components of TCCs. These figures are in line with conclusions drawn from earlier research conducted by PriceWaterhouseCoopers (PwC) and the World Bank Group (PwC and World Bank Group, 2011). According to this study, $61.5 \%$ of the compliance costs were caused by VAT, $25.5 \%$ by labor taxes and $13 \%$ by corporate taxes. It is remarkable-and reassuring for the validity of our results - that the relative percentage share of VAT, labor taxes and corporate tax is almost exactly the same for our results as it is in the study of the PwC and World Bank Group [in our study the share of VAT $=50 /(50+21+11)=61 \%$, the share of labor taxes $=21 /(50+21+11)=26 \%$, the share of corporate taxes $=11 /(50+21+11)=13 \%]$. However, the sum of the percentage shares is lower in our study $(82 \%)$, because our survey also explicitly asked the respondents 


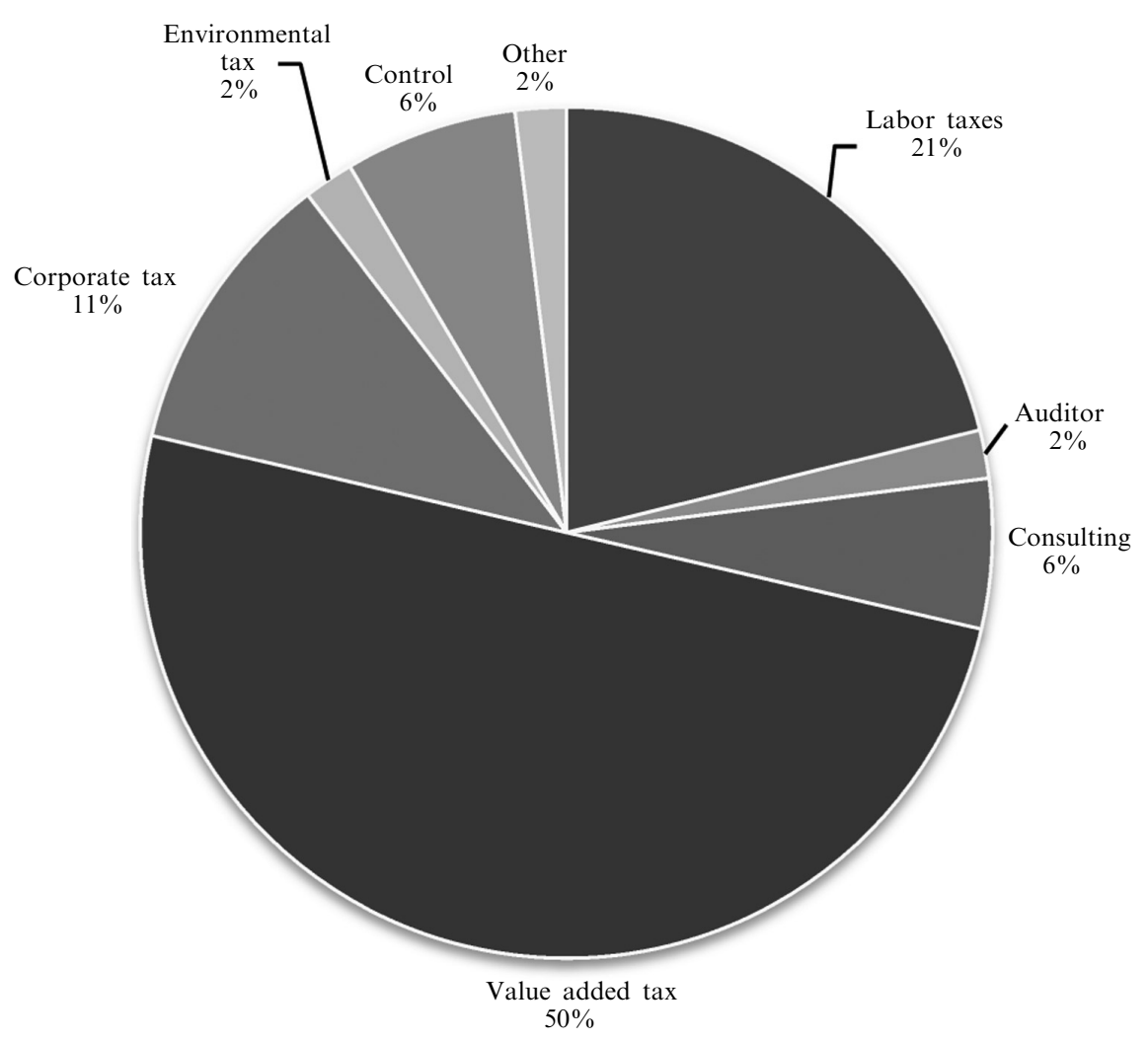

Figure 1. Breakdown total tax compliance cost.

to estimate the compliance costs of control $(6 \%)$, consulting $(6 \%)$, environmental taxes $(2 \%)$, and the auditor $(2 \%)$.

Figure 1 clearly reveals that VAT is responsible for the largest part of total TCCs. This is consistent with previous research (Blazic, 2005; Pope and Rametse, 2001; Smulders and Stiglingh, 2008; Vaillancourt, 1986) and can be explained by the fact that VAT must be calculated on a monthly basis by most companies. Cnossen and Verwaal (2002) show that firms registering their VAT less frequently (eg, quarterly or annually) have lower compliance costs than firms applying monthly filing frequencies. Furthermore, a complex taxation system exists for exporting companies, who are obliged to provide monthly information about their intercommunity (intra-EU) flows of goods. These administrative tasks can consume a lot of time, thereby increasing the total compliance costs.

Table 2 indicates that the average absolute compliance cost of an SME in our sample amounts to $€ 26230.54$. The absolute compliance cost varies between $€ 3824.70$ and $€ 80032.50$. The TCC relative to total assets is $2.1 \%$ on average. Relative to gross added value, the compliance cost is on average $7.1 \%$. This means that $7.1 \%$ of added value that is generated by Flemish SMEs serves to cover the cost of compliance with the Belgian tax regulations. Or, in analogy with the tax freedom day, which falls on the 8 June in Belgium, companies have to operate an additional sixteen (ie, $7.1 \% \times 220$ ) days in order to produce sufficient added value from which to cover TCCs. 


\subsection{Regressivity}

Table 4 reveals that TCCs are highly regressive, which is in line with previous studies on compliance costs (Blumenthal and Slemrod, 1992; Hanefah et al, 2002; Pope, 1993; Sandford et al, 1989; Slemrod and Venkatesh, 2002; Vaillancourt, 1986). SMEs with zero to twenty employees have a TCC relative to assets of $3.2 \%$, on average, while firms with more than twenty employees have an average relative TCC of only $0.7 \%$. This difference is significant on a $1 \%$ significance level. The aforementioned findings indicate that small SMEs have a relative TCC that is 4.7 times higher than that of larger SMEs. When we compare the TCC relative to gross added value between smaller and larger SMEs, similar conclusions can be drawn. Microenterprises $(<20$ employees $)$ have to spend on average $10.4 \%$ of their gross added value to comply with the tax legislation. For SMEs with more than twenty employees, this percentage is only $2.70 \%$. The results remain significant when we use fifty employees as a boundary.

Table 4. Regressivity.

\begin{tabular}{llrlll}
\hline Variable & $\begin{array}{l}\text { Number } \\
\text { of employees }\end{array}$ & $N$ & Mean & $\begin{array}{l}\text { Standard } \\
\text { error }\end{array}$ & $t$ \\
\hline TCC relative to assets & $0-20$ & 85 & 0.032 & 0.004 & $5.695^{* *}$ \\
& $>20$ & 61 & 0.007 & 0.001 & $4.246^{* *}$ \\
& $0-50$ & 112 & 0.027 & 0.003 & \\
& $>50$ & 34 & 0.004 & 0.001 & \\
TCC relative to gross added value & $0-20$ & 80 & 0.104 & 0.013 & $4.733^{* *}$ \\
& $>20$ & 59 & 0.027 & 0.008 & $3.538^{* *}$ \\
& $0-50$ & 105 & 0.088 & 0.010 & \\
& $>50$ & 34 & 0.020 & 0.011 &
\end{tabular}

${ }^{* *} p<0.01$.

Note: TCC - tax compliance cost.

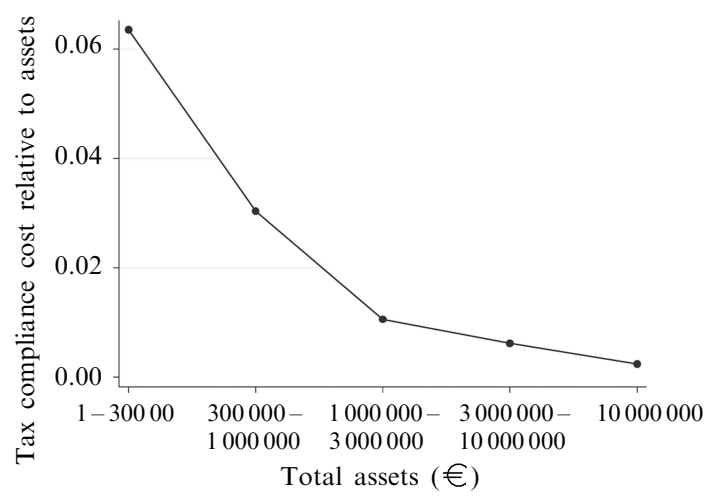

Figure 2. Regressivity plot.

In figure 2 the mean TCC relative to assets is plotted against total assets. When total assets is used as a measure of size instead of number of employees, again a clear 'regressivity pattern' can be found. Significant differences exist between the two smallest size classes (total assets of $€ 1-300000$ and $€ 300000-1000000$ ) and their larger counterparts. This affirms that microenterprises bear relatively higher compliance costs compared with larger firms. In combination with the underrepresentation of small firms in our sample, this regressivity pattern implies that our estimate of compliance cost as a percentage of added value of $7.1 \%$ is probably underestimated. 


\subsection{Other determinants}

Table 5(a) indicates that companies that partially outsource have a slightly higher compliance cost relative to gross added value. Partially outsourcing can increase TCCs as some tasks might be duplicated. However, the difference in relative compliance cost between partially outsourcing and nonpartially outsourcing firms is not significant in our sample. Industry, by contrast, does seem to be a determining factor of TCCs relative to assets. In the services industry the TCC relative to assets amounts to $3.5 \%$, while it is only $1.5 \%$ in the manufacturing industry. This difference is significant on a $1 \%$ significance level. These findings are partially in line with previous research on TCCs, since it has been shown that there exists a wide variation in TCC between different industries. However, no consensus exists about which exactly industries face the highest compliance costs. Contrary to the TCC relative to assets, the difference in TCC relative to gross added value does not prove to be significant. Table 5(c) shows that older firms have on average lower relative TCCs compared with their younger counterparts. It can be argued that older firms enjoy greater learning effects, by which TCCs might be decreased. Our results confirm this hypothesis, since the difference in TCC relative to assets between older and younger companies is significant. Contrary to TCC relative to assets, the difference in TCC relative to gross added value is not significant. Furthermore, the number of workers also seems to have an impact on the TCC relative to assets. Firms employing more than 50\% blue-collar workers have a substantially lower TCC relative to assets $(1.37 \%)$ than firms that mainly employ white-collar workers $(2.89 \%)$. In Belgium, white-collar workers often receive more fringe benefits than blue-collar workers. As fringe benefits cause considerable TCCs, it is logical that firms with a higher number of blue-collar workers face a lower TCC. The differences in TCC relative to assets and TCC relative to gross added value are significant on a $1 \%$ significance level.

Table 5(e) indicates that exporting firms (both inside and outside the European Union) have significantly lower relative TCCs than nonexporting firms. This seems counterintuitive, as exporting companies are normally expected to face a higher administrative tax burden. For instance, the tax legislation concerning intracommunity supplies of goods and services (trade inside the EU) is very complex, resulting in high prefiling TCCs. ${ }^{(5)}$ Furthermore, firms are obliged to provide monthly Intrastat declarations about their intracommunity flows of goods and services, which also induces compliance costs. Finally, firms that export outside the EU are subject to many administrative obligations with respect to customs, excise duties, etc, which can cause high prefiling and filing compliance costs. In order to rule out possible confounding effects from the other variables, we performed a number of covariance analyses. The results show that exporting status (ie a dummy having a value of one if a firm exports) remains significantly negatively related to TCCs (both relative to assets as relative to added value), even when controlling for firm size, age, outsourcing, industry, or the number of blue-collar workers.

\section{Sensitivity analyses}

As mentioned previously, an hourly rate of $€ 50$ for internal services and a rate of $€ 70$ for external services was used in order to calculate the absolute TCC. Although the external and internal accountants in our pilot study confirmed that these rates are representative for Belgian SMEs, they are to a certain extent arbitrary. In order to verify whether our results are not influenced by the chosen rates, sensitivity analyses were conducted. In table 6 the absolute and relative TCCs were recalculated using 
Table 5. Determining factors of tax compliance costs (TCCs): (a) outsourcing; (b) industry; (c) age; (d) number of blue-collar workers; (e) export status.

\begin{tabular}{lllll}
\hline Variable & Outsourcing $N$ Mean & $\begin{array}{l}\text { Standard } \\
\text { error }\end{array}$ \\
\hline
\end{tabular}

(a)

TCC relative to assets

$\mathrm{TCC}$ relative to assets

TCC relative to gross added value

TCC relative to assets

TCC relative to gross added value

\begin{tabular}{ll} 
Industry Mean $\quad \begin{array}{l}\text { Standard } t \\
\text { error }\end{array}$ \\
\hline
\end{tabular}

\begin{tabular}{lrrll}
\hline Manufacturing & 101 & 0.015 & 0.002 & $-4.052^{* *}$ \\
Services & 45 & 0.035 & 0.006 & \\
Manufacturing & 97 & 0.062 & 0.010 & -1.606 \\
Services & 42 & 0.092 & 0.018 & \\
Age & $N$ & Mean & $\begin{array}{l}\text { Standard } \\
\text { error }\end{array}$ & \\
\hline
\end{tabular}

TCC relative to assets

$\begin{array}{lrlll}<10 \text { years } & 19 & 0.038 & 0.008 & 2.709 * * \\ >10 \text { years } & 127 & 0.019 & 0.002 & \\ <10 \text { years } & 18 & 0.093 & 0.024 & 0.963 \\ >10 \text { years } & 121 & 0.068 & 0.009 & \end{array}$

\begin{tabular}{|c|c|c|c|}
\hline $\begin{array}{l}\text { Blue-collar } \\
\text { workers }(\%)\end{array}$ & $N$ & Mean & $\begin{array}{l}\text { Standard } \\
\text { error }\end{array}$ \\
\hline
\end{tabular}

\begin{tabular}{lllll}
\hline$<50$ & 73 & 0.029 & 0.004 & $3.262 * *$ \\
$>50$ & 73 & 0.014 & 0.002 & \\
$<50$ & 70 & 0.097 & 0.014 & $3.083 * *$ \\
$>50$ & 69 & 0.045 & 0.010 &
\end{tabular}

Export $\quad N \quad$ Mean $\begin{aligned} & \text { Standard } t \\ & \text { error }\end{aligned}$

TCC relative to assets

TCC relative to gross added value

\begin{tabular}{lllll}
\hline 0 & 58 & 0.032 & 0.005 & $3.748^{* *}$ \\
1 & 88 & 0.014 & 0.002 & \\
0 & 54 & 0.112 & 0.017 & $3.988^{* *}$ \\
1 & 85 & 0.045 & 0.008 &
\end{tabular}

$* * p<0.01$

different hourly rates. Logically, the absolute TCC diminishes as the rates are decreased. Since total assets and gross added value are unchanged, the relative TCC will also lessen when the applied rates are decreased. Table 5 indicates that the TCC relative to gross added value varies between $4.8 \%$ and $7.4 \%$. The TCC relative to assets fluctuates between $1.5 \%$ and $2.3 \%$. In all cases VAT, labor taxes, and corporate tax are the main causes of TCCs. Our regressivity results are also unchanged when using different rates. The smallest SMEs bear the highest relative TCCs. Hence, the sensitivity analyses show that the results in this study are not substantially influenced by the chosen hourly external and internal services rates. 
Table 6. Sensitivity analyses.

\begin{tabular}{lllll}
\hline Internal $(€)$ & External $(€)$ & $\begin{array}{l}\text { Average absolute } \\
\text { TCC }\end{array}$ & $\begin{array}{l}\text { TCC relative } \\
\text { to assets }\end{array}$ & $\begin{array}{l}\text { TCC relative } \\
\text { to GVA }\end{array}$ \\
\hline 50 & 70 & 26230.540 & 0.021 & 0.071 \\
50 & 50 & 25081.200 & 0.020 & 0.063 \\
30 & 40 & 18959.840 & 0.015 & 0.048 \\
70 & 50 & 30137.610 & 0.023 & 0.074
\end{tabular}

Note: GVA—gross added value; TCC—-tax compliance cost.

\section{Policy implications}

Our survey results indicate that Belgian SMEs bear considerably higher TCCs. Furthermore, it has been established that these compliance costs are strongly regressive in nature. Since a high tax burden might restrain firm growth, it is imperative that governments take measures to keep compliance costs as low as possible.

The Belgian government has already taken a number of initiatives in order to tackle the significant tax compliance burden that exists for SMEs. The objectives of these measures are twofold. First, the Belgian government intends to directly reduce the TCCs for small businesses. Second, by allocating various tax benefits to small companies, the government aims to alleviate the relatively high tax compliance burden that exists for these firms. For instance, the corporate tax rate for Belgian companies normally amounts to $33.99 \%$. However, for small businesses having a taxable income lower than $€ 322500$, there exists a reduced and progressive rate equaling $24.98 \%$ for the taxable income bracket between $€ 1$ and $€ 25000 ; 31.93 \%$ for the bracket between $€ 25000$ and $€ 90000$; and, finally, $35.54 \%$ for the $€ 90000-322500$ bracket. With respect to income tax withholding, small companies are allowed to deposit the amounts withheld from their employees quarterly, whereas larger companies have to pay monthly. A final example is the introduction of the VAT registration limit. Companies having a turnover that is less than $€ 5580$ are not liable to VAT registration. However, when compared with the VAT registration threshold in the UK, for instance (currently £70 000), this limit is quite low. Poutziouris et al (1999) argue that an increase in the VAT registration threshold might further reduce TCCs. In spite of the efforts that have already been made by the Belgian government, our results, nevertheless, clearly indicate that TCCs are still relatively high for small companies. Since high TCCs might impede innovation and growth, it is necessary that policy makers continuously strive to further reduce them. With this intention in mind, we formulate some suggestions.

First, governments should be aware of the educational function that they have with regard to the understanding and interpretation of the complex tax regulation. Companies often spend much time in analyzing the difficult and unstable tax legislation in order to find out which tax rules exactly apply to them in a certain tax year. Firms regularly even appeal to expensive tax experts to assist them in correctly interpreting the tax laws. Prefiling compliance costs are therefore often extremely high for certain taxes (eg, VAT). Consequently, simplifying tax legislation should be one of the major objectives of policy makers in order to decrease compliance costs. In addition, it is recommended that governments should develop information technology tools to facilitate the understanding, interpretation, and calculation of taxes for taxpayers. Guyton et al (2005) have already shown that the use of tax software might lower TCCs. 
A second recommendation concerns the timing of changes in tax legislation. In Belgium tax laws are very unstable, which is problematic in itself. In addition, the changes often become effective during the income year. For instance, in Belgium, luncheon vouchers were not tax deductible until 1 February 2009. Since then, luncheon vouchers have been deductible at $€ 1$ per voucher. This implies that for income year 2009 (tax assessment year 2010) companies had to apply two different tax rules: one for the month of January and one for the period February-December. The application of two (or more) different tax rules being effective consecutively in one income year complicates the calculation of taxable income to a considerable extent, thereby drastically increasing filing compliance costs. It therefore is recommended that governments relate the effective date of new tax legislation to a tax assessment year rather than to a predetermined date in the income year.

Third, governments increasingly aim to apply 'green taxation'. Notwithstanding the importance of encouraging sustainable entrepreneurship, the shift towards green taxation often causes high compliance costs. Additional 'reforming' taxes are implemented and existing taxes are modified, resulting in high prefiling compliance costs. Furthermore, filing costs can also augment to a large extent. In Belgium, for example, the tax deductibility of costs related to company cars has recently been linked to the emission of carbon dioxide $\left(\mathrm{CO}_{2}\right)$. Depending on the $\mathrm{CO}_{2}$ emission, car costs are deductible for $50 \%$ to $120 \%$. For firms having company cars with different emission rates, this regulation obviously causes a very complex and difficult calculation of the tax-deductible car costs. Compliance costs could be reduced by immediately taxing (accounting for the $\mathrm{CO}_{2}$ emission of the car) at the moment of purchase. It is thus advisable that governments, while striving for a more 'green' taxation, evaluate the impact of this new regulation on TCCs and seek to reduce compliance costs as much as possible.

Fourth, since some expenses that are recognized as costs for the purpose of financial reporting are not tax deductible, differences exist between accounting income and taxable income. As a result, firms must calculate both their accounting and taxable profit. Compliance costs could be significantly reduced by making all accounting costs tax deductible and thus by equating accounting income and taxable income. In Belgium most companies are obliged to draw up their financial accounts on a yearly basis. Consequently, firms would not have to make any additional compliance costs when they would be taxed on their accounting income. It can be argued that this approach could lead to an increase in the number of malpractices. On the other hand, tax inspectors would have more time to focus on the authenticity and legitimacy of the costs themselves instead of concentrating on the legitimacy of the tax rules that are applied.

A final recommendation concerns the consultation of fiscal experts. Governments often neglect to consult fiscal experts from the private sector when they plan to introduce new laws. As a consequence, the impact of new legislation on TCCs is frequently overlooked or underestimated. It would therefore be advisable that policy makers seek advice from fiscal experts and take their recommendations into account in order to keep compliance costs as low as possible. ${ }^{(6)}$

(6) An overview of 'best practices' that have already been implemented in Europe can be found in

"Models to reduce the disproportionate regulatory burden on SMEs" by the EC (2007). 


\section{Conclusion}

We have presented evidence, collected from a sample of Flemish SMEs, concerning TCCs. Belgium is already a country with one of the highest tax burdens in the world (Poutziouris et al, 2003). In addition, our results indicate that TCCs are significant, exceeding over $7 \%$ of added value. Furthermore, we confirm the regressivity hypothesis, found in other empirical work. Obviously, like all surveys in this field, ours is not without limitations. One weakness is that we do not attempt to separate accounting from TCCs. There are taxpayers who regard all costs involved in the preparation of accounting as compliance costs, because taxation is the only reason that they have an accounting system. For other companies tax compliance is only one byproduct of their accounting system (Tran-Nam et al, 2000). Given the already detailed and timeconsuming nature of our survey, we limited ourselves to tax compliance tasks and did not inquire specifically about accounting functions. This may potentially have biased our estimates of compliance costs upwards, especially for smaller companies. On the other hand, nonlabor compliance costs - as in most studies - have been ignored. This probably causes underestimation of the true compliance costs to some extent. Furthermore, we did not take into account the tax benefits that the deductable compliance costs generate. To do so would require knowledge of the effective marginal tax rates per company, which was not available to us. As a consequence, our measure of compliance costs is gross or before tax. Finally, there are probably also benefits in terms of improved management knowledge, better tax planning opportunities, etc, forthcoming from compliance activities, which are also not taken into account.

The increasing tax complexity in many countries, together with the growth of the importance of the small business sector, has raised the awareness concerning TCCs for SMEs. In response to this public awareness, some governments, for instance in the UK and Australia, accompany new tax legislation with some form of compliance cost impact statement. Although it seems appropriate to simplify the taxation system in order to decrease compliance costs, policy makers counterargue that taxes can be useful in reforming the economy (Gunz et al, 1995; Kitching, 2006). Environmental taxes, for example, can stimulate an evolution towards durable economic growth. Governments clearly need to make a difficult trade-off between tax simplifications resulting in lower compliance costs and introductions of new tax regulations in order to stimulate desirable economic behavior.

Future research might investigate whether the beneficial effects of additional reforming taxes outweigh the high costs of a complex tax system. Furthermore, it might be interesting to empirically evaluate the effects of high compliance costs on the performance, growth, profitability, innovation, etc of firms. Until now, research has mainly focused on the magnitude and determinants of TCCs. The possible consequences of a burdensome taxation system are, by contrast, highly underresearched. Another issue for future research is our counterintuitive finding that compliance costs are higher for nonexporting companies.

\section{References}

Ariff M, Ismail Z, Loh A, 1997, "Compliance costs of corporate income taxation in Singapore" Journal of Business Finance and Accounting 241253 - 1268

Armstrong J, Overton T, 1977, “Estimating nonresponse bias in mail surveys” Journal of Marketing Research $14396-402$

Blazic H, 2005, "Tax compliance costs for companies in Slovenia and Croatia" Finanz Archiv 61 $418-437$

Blumenthal M, Slemrod J B, 1992, "The compliance cost of the US individual income tax system: second look after tax reform" National Tax Journal 45 185-202

Blumenthal M, Slemrod J B, 1996, "The income tax compliance costs of big businesses" Public Finance Quarterly $24411-438$ 
Chan S, Cheung D, Ariff M, Loh A, 1999, "Compliance costs of corporate taxation in Hong Kong" International Tax Journal $2542-69$

Chittenden F, Poutziouris P, Michaelas N, Watts T, 1999, "Taxation and small firms: creating incentives for the reinvestment of profits" Environment and Planning C: Government and Policy $17271-286$

Chittenden F, Kauser S, Poutziouris P, 2003, "Tax regulation and small business in the USA, UK, Australia and New Zealand" International Small Business Journal $2193-115$

Chittenden F, Kauser S, Poutziouris P, 2005, "PAYE-NIC compliance costs: empirical evidence from the UK SME economy" International Small Business Journal 23 635-656

Cnossen S, 1994, "Administrative and compliance costs of the VAT: a review of evidence" Tax Notes $631609-1626$

Cnossen S, Verwaal E, 2002, "Europe's new border taxes" Journal of Common Market Studies 40 $309-330$

Collard D, Godwin M, 1999, "Compliance costs for employers: UK PAYE and national insurance 1995 - 96" Fiscal Studies 20423 - 449

Coolidge J, Ilic D, Kisunko G, 2009, "Small businesses in South Africa: who outsources tax compliance work and why?”, WP 4873, Policy Research Working Paper, World Bank, Washington, DC

EC, 2007, "Models to reduce the disproportionate regulatory burden on SMEs", European Commission, Brussels, http://ec.europa.eu/enterprise/policies/sme/files/support_measures/ regmod/regmod_en.pdf

Gunz S, MacNaughton A, Wensley K, 1995, "Measuring the compliance costs of tax expenditures: the case of research and development incentives" Canadian Tax Journal 432008 - 2034

Gurd B, Smith M, Turner J L, 1998, "Auditing income tax self-assessment: the hidden cost of compliance" Journal of Managerial Auditing $1395-100$

Guyton J L, Korobow A K, Lee P S, Toder E J, 2005, "The effects of tax software and paid preparers on compliance costs" National Tax Journal 58439 - 448

Hanefah M, Ariff M, Kasipillai J, 2002, "Compliance costs of small and medium enterprises" Chartered Accountants Journal $473-94$

Hansford A, Hasseldine J, Howorth C, 2003, "Factors affecting the costs of UK VAT compliance for small and medium-sized enterprises" Environment and Planning C: Government and Policy $21479-492$

Holtzman Y, 2007, "Challenges in achieving transparency, simplicity and administering of the United States tax code" Journal of Management Development 26418 - 427

Kitching J, 2006, "A burden on business? Reviewing the evidence base on regulation and smallbusiness performance" Environment and Planning C: Government and Policy 24 799-814

O'Reilly P, 2005, "SMEs hard-hit by compliance costs" Chartered Accountants Journal November, page 15

Pope J, 1993, "The compliance costs of taxation in Australia and tax simplification: the issues" Australian Journal of Management 18 69-89

Pope J, Rametse N, 2001, "Small business and the goods and services tax" Small Enterprise Research $942-54$

Poutziouris P, Chittenden F, Michaelas N, 1999, "Modelling the impact of taxation on the smallbusiness economy: the NatWest/MBS tax index for the self-employed, sole-traders, and partnerships" Environment and Planning C: Government and Policy 17 577-592

Poutziouris P, Chittenden F, Watts T, Soufani K, 2003, "A comparative analysis of the impact of taxation on the SME economy: the case of UK and US - New York State in the year 2000" Environment and Planning C: Government and Policy $21493-508$

PwC, Federation of Enterprises in Belgium, 2009, "Total tax contribution", PricewaterhouseCoopers and the Federation of Enterprises in Belgium, Brussels, http://www.vbo-feb.be/index.html?page $=165$

PwC, World Bank Group, 2008, "Paying taxes 2008”, Price WaterhouseCoopers and the World Bank Group, http://www.pwc.com/en_GX/gx/paying-taxes/pdf/paying_taxes_2008.pdf

PwC, World Bank Group, 2011, "Paying taxes 2011", PricewaterhouseCoopers, and the World Bank Group, http://www.pwc.com/gx/en/paying-taxes/pdf/paying-taxes-2011.pdf

Sandford C, 1995 Tax Compliance Costs: Measurement and Policy (Fiscal Publications, Bath, Somerset)

Sandford C, Godwin M, Hardwick P, 1989 Administrative and Compliance Costs of Taxation (Fiscal Publications, Bath, Somerset) 
Slemrod J, 2004, “Are corporate tax rates, or countries, converging?” Journal of Public Economics $\mathbf{8 8}$ $1169-1186$

Slemrod J, Venkatesh V, 2002, "The income tax compliance cost of large and mid-size businesses", paper no. 914, Ross School of Business, Ann Arbor, MI

Smulders S, Stiglingh M, 2008, "Annual tax compliance costs for small businesses: a survey of tax practitioners in South Africa" South African Journal of Economic and Management Sciences $11354-371$

Soufani K, 2003, "Small business growth and tax policy in Canada-a theoretical model" Environment and Planning C: Government and Policy $21567-578$

Tran-Nam B, Evans C, Walpole M, Ritchie K, 2000, "Tax compliance costs: research methodology and empirical evidence from Australia" National Tax Journal 53 229-252

Vaillancourt F, 1986, "The compliance costs of taxes on businesses and individuals: a review of the evidence" Public Finance $42395-419$

Vandenbussche H, Crabbé K, Janssen B, 2005, "Is there regional tax competition? Firm level evidence for Belgium" De Economist 153 257-276 
Appendix. Taxes in Belgium (source: PwC and Federation of Enterprises in Belgium, 2009).

\section{Product taxes}

Irrecoverable value-added tax (VAT)

\section{Net VAT}

Tax on stock exchange transactions

Tax on carry-over transactions

Tax on delivery or bearer securities

Insurance premium tax

Tax on long-term savings

Withholding tax on benefits that result from occupational benefit schemes

Withholding tax on benefits that result from life insurance and pension savings contracts

Health insurance contributions on the civil aspect of car insurance

Contributions on hospitalization insurance

Contributions on fire insurance, car insurance, and industrial accident insurance

Contribution on insurance contracts for the Belgian Red Cross

Contribution to the security fund for fire and explosion

Betting and gaming taxes paid to the tax authorities Gaming machine license duty paid to the tax authorities

Horse racing betting shop tax

Tax on office areas

Tax on employed staff

Bill-posting taxes

Advertising hoardings tax

Tax on motor power

Tax on computer screens

Bank and financial institutions tax

ATM tax

Tax on trading areas

Car park tax

Vending machine tax

Tax on liquor store opening (Wallonia only)

Patent tax

Tax on pylons

Net asset tax

Annual tax on coordination centers

Special tax on bearer bonds held by financial intermediaries

Special tax on retained profits of certain credit institutions

Contributions on fire insurance, car insurance and industrial accident insurance

Annual estate tax for pension funds

\section{Environmental taxes}

Carbon dioxide solidarity contribution on

company cars

Ecotaxes

Environment contribution

Tax on industrial packaging

Tax on waste

Sewerage tax

Tax on printed advertising materials

Tax on the discharge of waste water

Levy on surface water catchments

Tax on underground water

Tax to combat and prevent empty and abandoned business premises and the decay of buildings
Product taxes (continued)

Contribution to the Banking Commission

Customs duties

Excise duties on mineral oil

Energy contribution (only on electricity)

Federal contribution on energy

Car registration tax

Road tax

Additional road tax

Compensatory excise tax

Road toll (Eurovignette)

Municipal road tax

Excise duties on tobacco products

Excise duties on alcoholic beverages

Excise duties on other beverages

Packaging contribution

Annual tax on profit sharing

Profit taxes

Corporate tax

Yearly company contribution

Withholding tax on income from investment

Country or residence tax withheld at source

Pharma levy

Regional tax on companies

Provincial tax on companies

Elia tax

Property taxes

Property tax

Stamp duty

Registration duties

Employment taxes

Employer social security contribution

Withholding tax on professional income

Employee social security contribution

Special social security contribution

Tax on employee equity participation and employee participation in profits and corporate results

Contributions on pensions

Pension solidarity contribution

Environmental taxes (continued)

Tax on hazardous, insalubrious and impracticable establishments

Urban development levy

Food safety tax

Major accident hazard levy for certain industrial activities

Ionizing radiation levy

Hazardous substances levy

Fixed tank tax

Tax on distribution apparatus for liquid or gaseous fuels

Tax on scrap metal and scrap vehicle dumps

Gravel tax 
Conditions of use. This article may be downloaded from the E\&P website for personal research by members of subscribing organisations. This PDF may not be placed on any website (or other online distribution system) without permission of the publisher. 